\title{
Resilience of Tree Species to Floods and Rehabilitation Strategy for the Flood Affected Indus Basin
}

\author{
Muhammad Imran Mahmood* and Muhammad Zubair
}

Department of Forestry and Range Management, Faculty of Agriculture Sciences and Technology, Bahaud-Din-zakariya University, Multan, Pakistan.

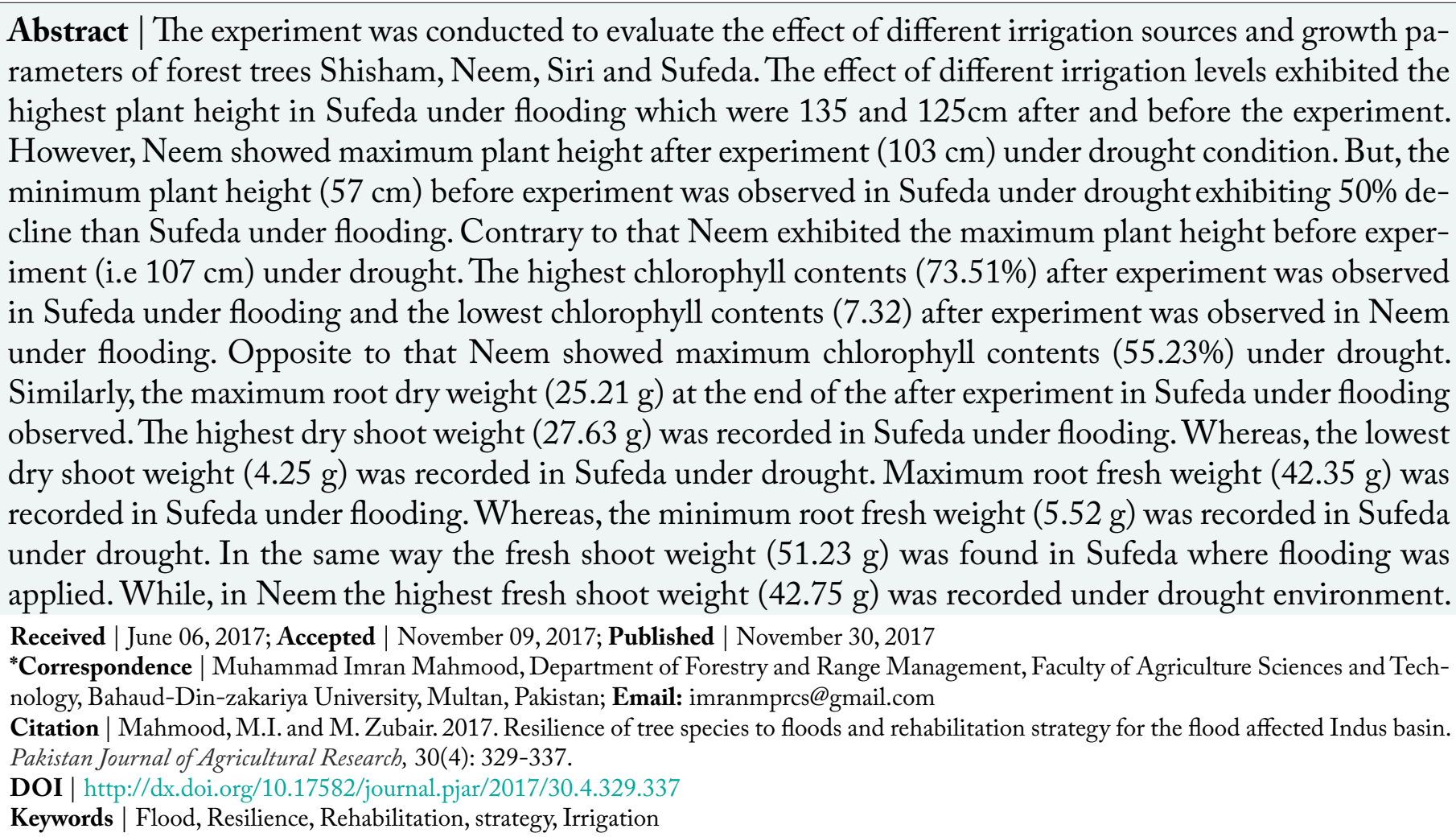

\section{Introduction}

$\mathrm{F}$ orests are foundations for human beings well-be-

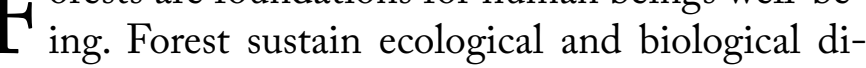
versity and protection of habitat and water resources. Resilient forests have uniqueness to accommodate gradual changes to climate but have a propensity to return toward its prior condition after shock with management assistance (Spittlehouse and Stewart, 2004). In forest ecosystems resilience can be improved through practices related to those described to resist change, more broadly, and specifically intended to cope with disturbance (Dale et al., 2001; Wheaton 2001). Pakistan is deficient in forest resources covering only $5.2 \%$ of its total land area (Anonymous, 2011). Similarly per capita forest area is only 0.03 compared to developing and developed countries average of 0.5 and 1.07 hectares respectively. Deforestation rates are also highest in the reaching 1.1percent $(55,000$ hectares) per annum (Alam et al., 2006).

The major function of forest is the production of December 2017 | Volume 30 | Issue 4 | Page 329 
wood and non-wood products that accounts for 1.2 billons? (FAO, 2010). The forest resources provide job opportunities to rural people in Pakistan (Iqbal, 1991). It is reported that globally significance of trees outside forests, like agriculture land, it cover almost half of the agricultural land has tree of more than 10 percent (Zomer et al., 2009). Increase in food insecurity and deteriorating livelihood situations call for intensive and rigorous actions at national and international levels to harvest benefits of huge potential of agroforestry among other system and for supporting best land use practices (EI- lakany, 2004).

Flood as a natural disaster has large scale direct costs on the community/society, mainly for the rural inhabitants of developing countries. It is observed that across the globe numerous major flood events hit various regions such as China, India, Australia; Eastern part of the USA and Central Europe due to climatic change.

According an estimate more than 196 million people and $65 \%$ of the World's mass are prone to the flood (Dilley et al., 2005). It is evident that intensity and frequency of flood events has been raised (Hirrabayashi et al., 2013). Pakistan is place in the world where floods event has been increased. The Indus river basin, which crosses through approximately $75 \%$ of the country area (Kazi, 2014). Since 1947 the river basin has been affected by thirteen major floods (Azam et al., 2012), major catastrophe in term of human loss (about, 2000 casualties) and assets destruction was flood 2010 (Rafique and Blaschke, 2012).

Ecological /natural disasters have been occurring more frequently in China, natural disasters in year 2012, approximately affected about 290 million people and colossal loss of 418.55 billion yuan (MCA, 2012). The field crops grown in monoculture systems are particularly, vulnerable to climatic change, biotic stresses and natural disaster (Hirrabayashi et al., 2013). In contrary, agroforestry is a form of diversified farming practice, which is more resilient against natural shocks (Cabell and Oelofse, 2012).

Forest-covered slopes in the tropics are relatively stable given the strength of underlying soil and bedrock when they are augmented by the long-term woody vegetation (Restrepo et al., 2009; Sidle, 2010). The diversified agroforestry as it provide us timber, fruit and fuelwood species has served as buffer for sustainable natural resource (Cullen et al., 2005). World agriculture regions are facing new expectations for performance; one is the sustainable livelihoods for farming communities, restoring biodiversity and providing resilience (UNDESA, 2012). Douglas (2009) determined that in South Asia most vulnerable groups in term of food security during floods are poor, women and children.

Floods remained the main factor affecting growth of trees especially young trees. Persistent water creates water logged conditions which adversely induce physiological and biochemical changes affecting photosynthetic activity. Kot Addu and Layyah were the worst hit areas in 2010 floods and spill over affect of the water is a common feature almost every year. Present research, was designed for understanding the resilience of some species over others and propagation of such species would yield numerous benefits and extend the role of agroforestry to contribute towards livelihood of flood affected communities of Kot Addu and Layyah.

The concept of resilience in agroforestry emerged in that how a system when exposed to a disaster has the capacity to withstand, accommodate and recover from the ill effects by restoring or preserving its function (UNISDR, 2009). Flood havoc of the Indus basin initiated in mid-July of 2010 and continued till early September thereby affecting the lives of more than 14 million people in Pakistan. According to (EM-DAT, 2010) Pakistan's' floods history divulge that in 1950, 1973,1976,1988,1992, and 1997 floods consequently resulted in enormous number of deaths and severe loss of property (NDMA, 2010a). The recent abnormal July 2010 catastrophic floods have been described as the worst in the last eighty years and led to profound effects on human life, property, and economy in Pakistan. The magnitude of 2010 flood was high both scale and destruction in comparison to the earthquake of 2005, Indian Ocean Tsunami 2004, cyclone Nargis, 2008 and Haiti Earthquake 2010 (NDMA, 2010b) Nearly 20 million people being significantly affected by flood 2010 (UNDESA, 2012). Globally, floods affect the personal and economic fortunes of more than 60 million people each year (FAO, 2010).

In areas affected by floods some species keep their submerged leaves for some flooded period, whereas others usually shed within few days of submergence. The floods have an adverse affects on stomatal con- 
ductance thereby affecting rate of photosynthesis after approximate one month of flooding (Herrera et al., 2008). When photosynthetic activity is decreased during flooded condition, the output of photosystem II also reduced, suggesting that part of the reduction in photosynthetic rate was due to impairment of photosynthetic capacity, which change leaf anatomy. The manifested changes in photosynthetic capacity may also be result in change in total soluble protein and chlorophyll content (Herrera et al., 2008) that in turn reflect anatomical variables, including number and size of parenchymatous cells. Changes in specific leaf area of flooded trees due to changes in wholeleaf thickness, number of cell layers amount of sclerenchyma could modify mesophyll conductance and hence photosynthetic rate (Niinemets et al., 2009). Flooding may caused changes in Stomatal density (SD) thereby affecting leaf gas exchange.

Finding of the present study will be helpful in identifying various resilient species that could be helpful in saving premiums to farmers in the wake of floods thereby helping in sustenance of their livelihoods in pertinent flood damages.

\section{Materials and Methods}

\section{Location}

Seedlings of Shisham (Dalbergia sissoo), Neem (Azadiracbta indica), Siri (Albizia lebbeck) and Sufeda (Eucalyptus camaldulensis) were raised in nursery of the Department of Forestry \& Range Management, Forestry Faculty of Agricultural Science and Technology, BZU, Multan, Pakistan (Latitude $30.263^{\circ} \mathrm{N}$, Longitude $071.506^{\circ} \mathrm{E}$ ) during 2014 to 2015.

\section{Plant material}

After one year of emergence, local stock seedling were used (plant sampling) was obtained from nursery and these were transplanted into containers $(30 \mathrm{~cm}$ depth, $22 \mathrm{~cm}$ width). The pots were filled with clay loam soil obtained from a nearby stream. The soil was collected from the University Nursery area which was clay loam soil obtained. One plant sapling of each species was transplanted into individual pot being considered as one experimental unit. The plants (one plant per pot) were grown in a research area and watered daily.

\section{Field capacity measurement}

The soil field capacity and Available Water Content
(AWC) measured in the laboratory. The AWC for the species under experiment were supposed to be $70 \%$ and $10 \%$ for flooding and drought, respectively. Each species was replicated thrice under controlled environment. The soil moisture contents for flooding and drought were maintained by applying calculated quantity of water on daily basis. For accurate measurement of drought the counting of days were performed till the AWC in the soil reached to about 10\%.

\section{Flooding treatment}

Different flooding irrigation were induced by placing the seedlings in (30 cm depth, $22 \mathrm{~cm}$ width) plastic buckets, filled with water to $2 \mathrm{~cm}$ above the soil level, with one seedlings per bucket. In flood treatments, all growth variables were measured in only one seedling per bucket. At the beginning of the experiment all seedlings had vigorous visual appearance; therefore seedlings were not fertilized during the experiment. In order that the light environment and soil flooding would remain the main variables controlling photosynthesis and growth, control the seedlings were kept well watered. In flooded seedlings, as the water evaporated from bucket and these were replaced to keep the level of water at $2 \mathrm{~cm}$ above the soil surface. Pots were modified to allow drainage through tubes attached to the bottom of each container; any leachate was collected in designated traps and returned to the container daily. However, in flood treatments growth variables and all photosynthetic were measured from only one seedling per bucket.

After the initial 10 days of transplantation, acclimation period, the seedlings plant or sampling. At the conclusion of the study, tissue samples from foliage and roots were collected from the study plants for nutrient determination. Samplings were subjected to three soil water treatments: Drought, normal irrigation and permanently flooded to two $\mathrm{cm}$ above the soil surface. The experiment was conducted in completely randomized design (CRD) with three replications. Each pot containing one plant was considered as one replication. Effect of mentioned treatments on plant performance was assessed based on growth parameters like plant height, collar diameter, number of branches, shoot and root fresh and dry weight, and chlorophyll contents. The chlorophyll contents were determined through SPAD (MODEL502 Minolta Japan). Plant leaves from each species were selected to measure chlorophyll contents which were grown under drought-stress, normal and flooded conditions. 
Plant dry weights

Sampling dry weight and partitioning were determined at the conclusion of the experiment (day 70) by harvesting the plants and separating each sample plant into leaf, branches and root components. Plant components were then dried at $70^{\circ} \mathrm{C}$ for 48 hours to a constant weight and dry weights were recorded.

Data were recorded about the plant height $(\mathrm{cm})$ diameter $(\mathrm{cm})$ chlorophyll contents of leaves (\%) numbers of branches and seedling root and shoot biomass (gm).

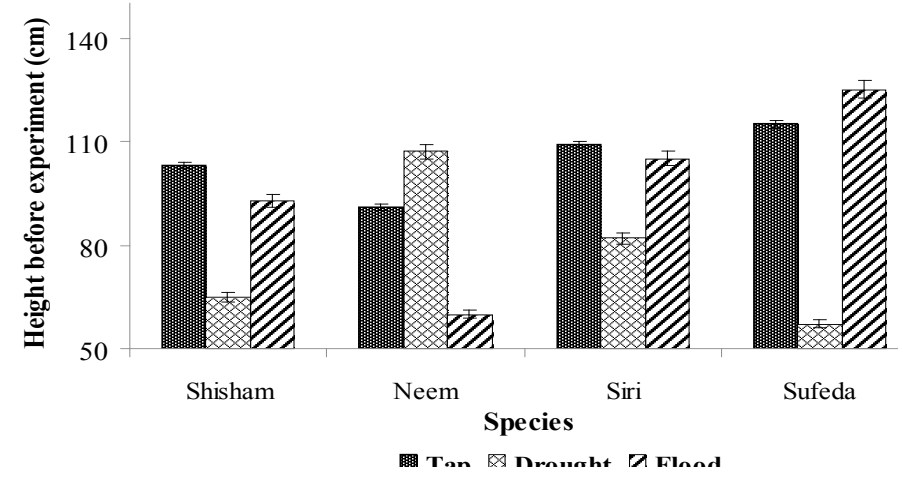

Figure 1: Plant height before experiment.

\section{Results and Discussion}

\section{Plant height before experiment}

The impacts of different irrigation levels on various tree species is represented in Figure 1. The effect of different irrigation levels indicated the maximum plant height before experiment in Sufeda where flooding was applied $(125 \mathrm{~cm})$ which was followed by $115 \mathrm{~cm}$ in Sufeda (Eucalyptus camelduluences) under $\mathrm{T}_{1}$ treatment. But, the minimum plant height $(57 \mathrm{~cm})$ before experiment was observed in Sufeda (Eucalyptus camelduluences) under drought exhibiting 50\% decline in plant height in Sufeda (Eucalyptus camelduluences) where drought was applied than Sufeda under flooding treatment. However, the Neem (i.e Azadirachta indica) exhibited the maximum plant height before experiment (i.e $107 \mathrm{~cm}$ ) in drought.

\section{Plant height at the end of experiment}

The data regarding the effect of irrigation levels on various tree species is presented in Figure 2. The effect of Different irrigation levels exhibited the highest plant height after experiment in Sufeda where flooding was applied $(135 \mathrm{~cm})$ followed by $127 \mathrm{~cm}$ in the same species Sufeda (Eucalyptus camelduluences) where $T_{1}$ was applied. Whereas, the lowest plant height $(27 \mathrm{~cm})$ after experiment was observed. How ${ }^{-}$ ever, Neem (Azadirachta indica) showed maximum plant height after experiment (i.e $103 \mathrm{~cm}$ ) under drought.

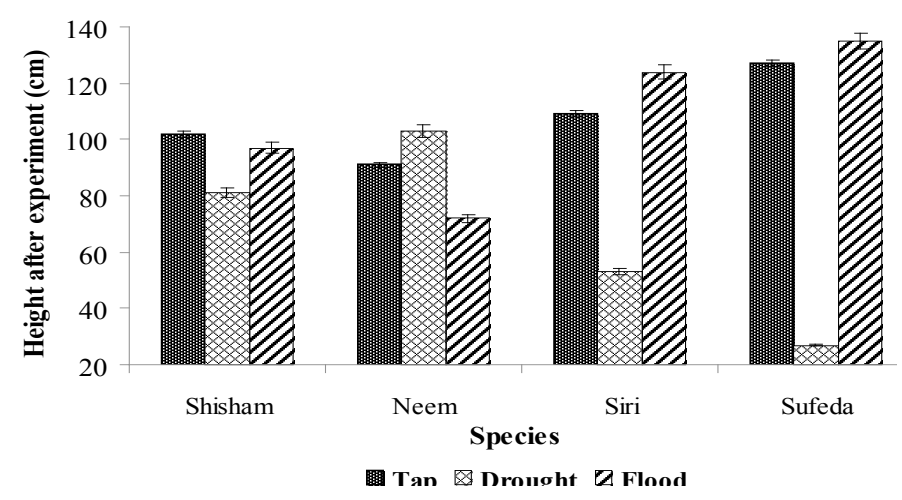

Figure 2: Plant height after experiment.

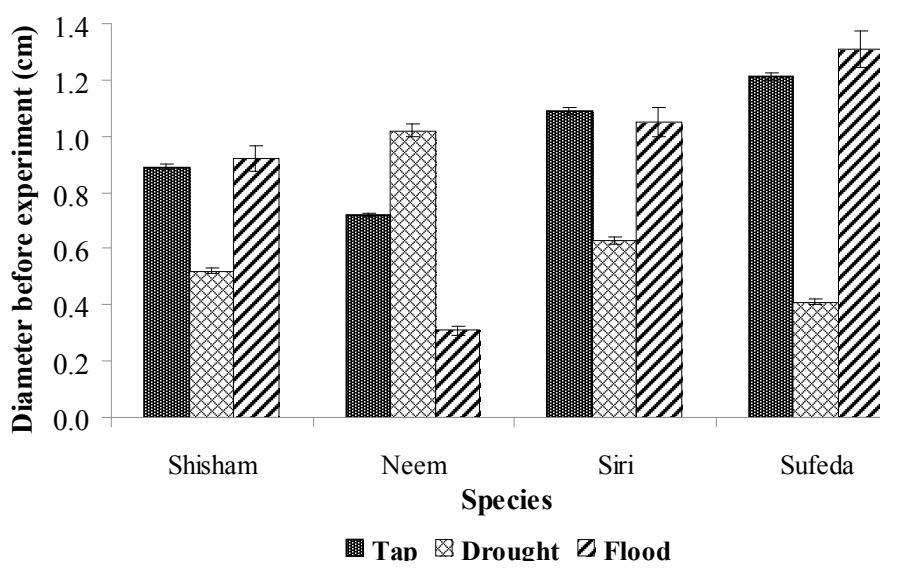

Figure 4: Plant diameter after experiment.

\section{Plant diameter before and after experiment}

Figure 4 is showing the effect of irrigation levels on various tree species. The results highlighted that the effect of different irrigation levels on the plant diameter after experiment which were statistically significant. The highest plant diameter after experiment which was observed in Sufeda where flooding was applied $(8 \mathrm{~cm})$ followed by $7 \mathrm{~cm}$ in the same specie Sufeda (Eucalyptus camelduluences) where $\mathrm{T}_{1}$ was applied. Whereas, the lowest plant diameter $(2 \mathrm{~cm})$ after experiment was observed in Neem and Sufeda (Eucalyptus camelduluences) under drought in Neem and Sufeda, respectively. However, Neem (Azadirachta indica) showed maximum plant diameter (i.e $7 \mathrm{~cm}$ ) under drought condition.

The data regarding irrigation levels impact on various tree species is given in Figure 3. The effect of different irrigation levels exhibited the highest plant diameter before experiment in Sufeda (Eucalyptus camelduluences) where flooding was applied $(6.31 \mathrm{~cm})$ fol- 
lowed by $4.63 \mathrm{~cm}$ in Neem (Azadirachta indica) where drought was applied. Whereas, the lowest plant diameter $(2.52 \mathrm{~cm})$ before experiment was observed in $\mathrm{S}_{1}$ under drought.

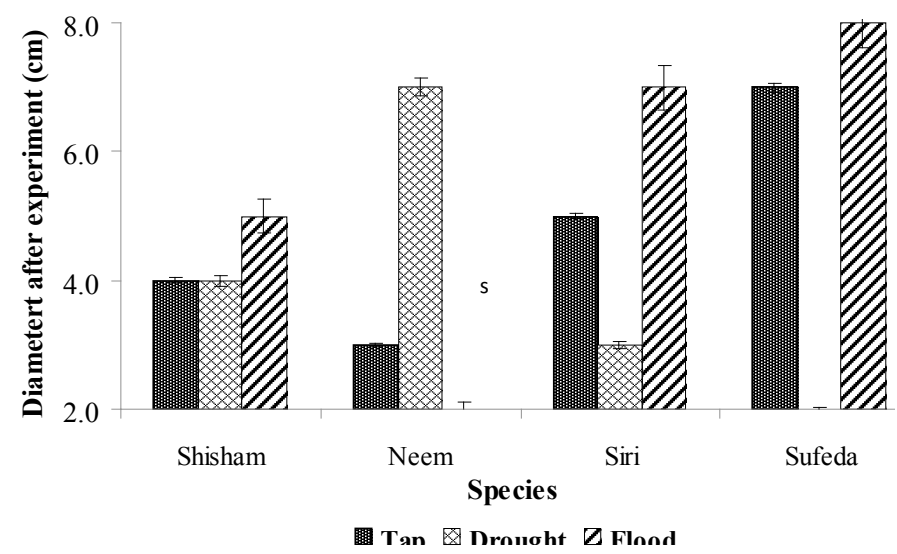

Figure 3: Plant diameter before experiment.

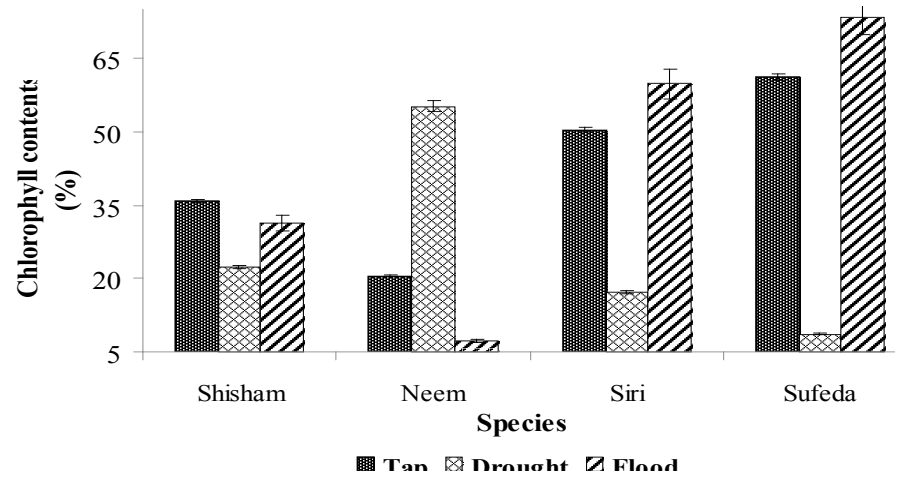

Figure 5: Chlorophyll contents as influenced by irrigation levels.

\section{Chlorophyll contents}

Figure 5 is showing the effect of irrigation levels on chlorophyll contents of various tree species. The results highlighted that the effect of different irrigation levels on chlorophyll contents of pant after experiment were statistically significant. The highest chlorophyll contents (73.51) after experiment was observed in Sufeda where flooding was applied followed by 61.23 in the same specie Sufeda (Eucalyptus camelduluences) where $\mathrm{T}_{1}$ was applied. Whereas, the lowest chlorophyll contents (7.32) after experiment was observed in Neem (Azadirachta indica) under flooding. However, Neem showed maximum chlorophyll contents (i.e 55.23\%) under drought.

\section{Root dry weight}

The data regarding irrigation levels impact on root dry weight of various tree species is given in Figure 6. The effect of different irrigation levels exhibited the highest root dry weight $(25.21 \mathrm{~g})$ after experiment in Sufeda where flooding was applied followed by $24.84 \mathrm{~g}$ in Sufeda where drought was applied.
Whereas, the lowest root dry weight (3.51 g) was recorded in Neem (Azadirachta indica) under flooding. The highest dry weight in sufeda (Eucalyptus camelduluences) under flood irrigation was the result of high water needs of sufeda (Eucalyptus camelduluences) which showed accelerated growth under plenty of available water.

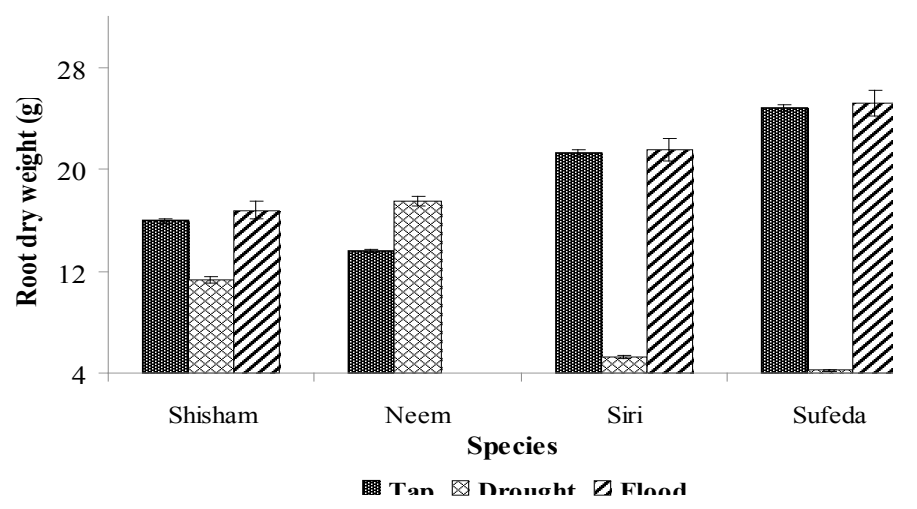

Figure 6: Root dry weight.

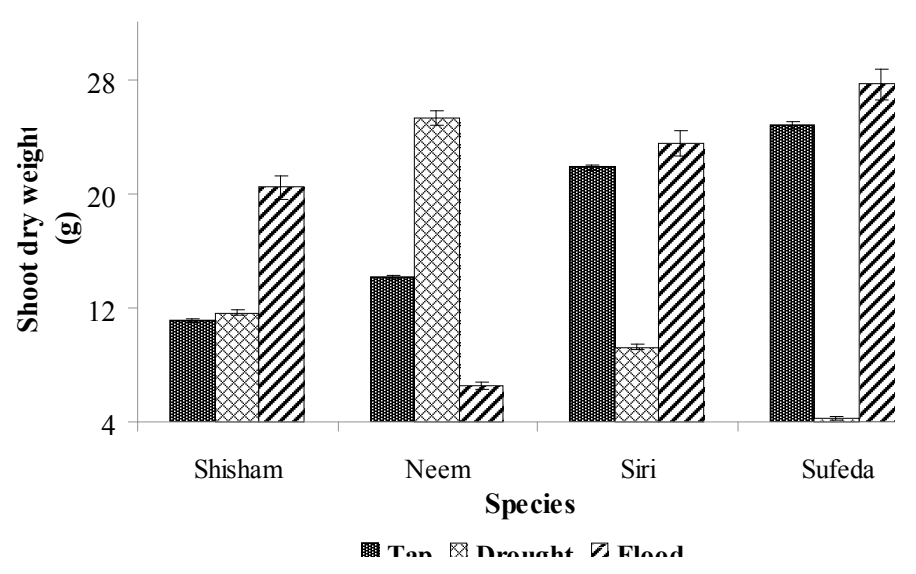

Figure 7: Dry shoot weight.

\section{Dry shoot weight}

The data regarding impact of irrigation levels on dry shoot weight of various tree species is given in Figure 7. The effect of different irrigation levels exhibited the highest dry shoot weight $(27.63 \mathrm{~g})$ in Sufeda (Eucalyptus camelduluences) where flooding was applied followed by $25.25 \mathrm{~g}$ in Neem where drought was applied. Whereas, the lowest dry shoot weight (4.25 g) was recorded in Sufeda (Eucalyptus camelduluences) under drought. This much high dry shoot weight of Sufeda (Eucalyptus camelduluences) under flood irrigation was due to optimal supply of salts and water under optimum supply of water with concomitant increase in dry shoot weight.

\section{Root fresh weight}

The data regarding impact of irrigation levels on root fresh weight of various tree species are given in Figure 
8. The effect of different irrigation levels exhibited the highest root fresh weight $(42.35 \mathrm{~g})$ in Sufeda where flooding was applied followed by $38.40 \mathrm{~g}$ in Neem (Azadirachta indica) where drought was applied. Whereas, the lowest root fresh weight $(5.52 \mathrm{~g})$ was recorded in Sufeda (Eucalyptus camelduluences) under drought.

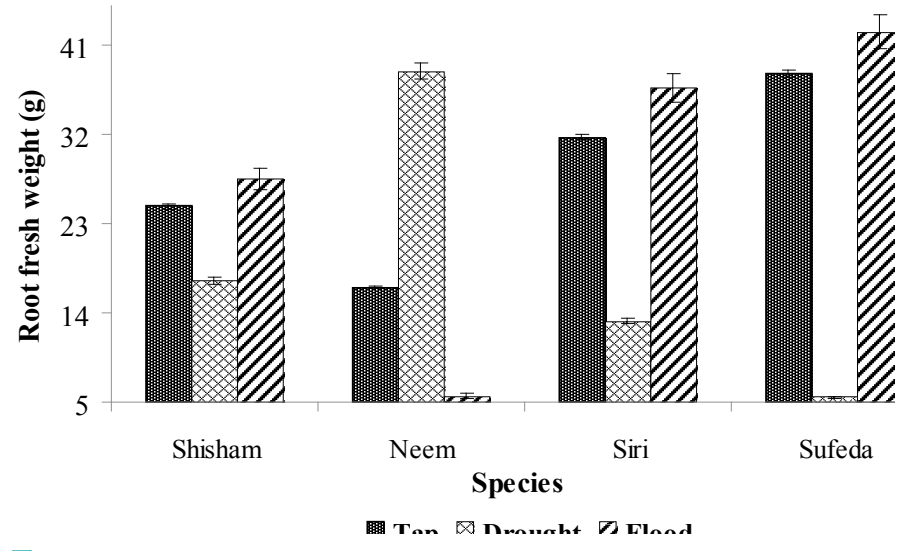

Figure 8: Root fresh weight.

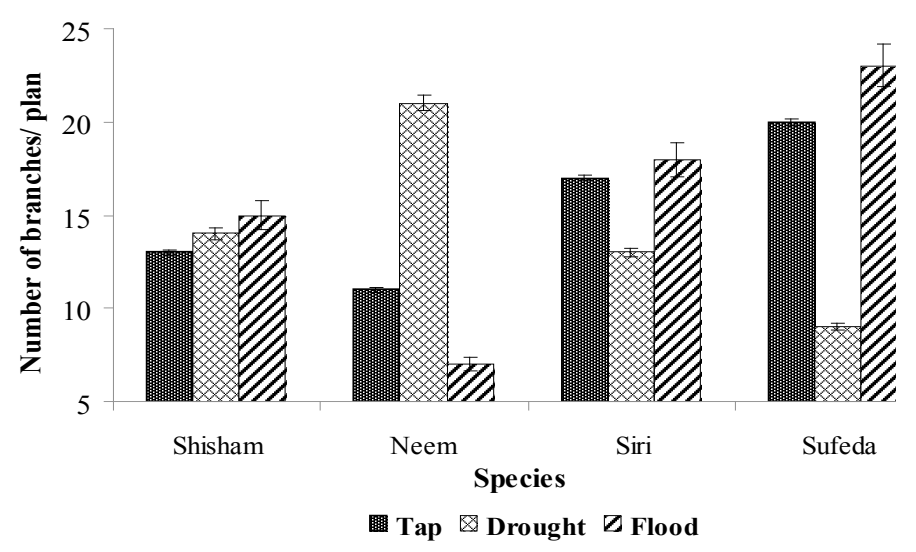

Figure 9: Plant branches.

\section{Plant branches}

The data regarding impact of irrigation levels on plant branches of various tree species are given in Figure 9. The effect of different irrigation levels exhibited the highest plant branches (23) in Sufeda where flooding was applied followed by 21 in Neem (Azadirachta indica) where drought was applied. Whereas, the lowest plant branches (7) were recorded in Neem under flooding. As Sufeda (Eucalyptus camaldulensis) is a water loving plant with high water demand therefore it showed highest number of branches under flooding (i.e flooding).

\section{Fresh shoot weight}

The data regarding impact of irrigation levels on fresh shoot weight of various tree species is given in Figure 10. The effect of different irrigation levels exhibited the fresh shoot weight (51.23 g) in Sufeda (Eucalyptus camaldulensis) where flooding was applied followed by $47.76 \mathrm{~g}$ in Neem where $\mathrm{T}_{1}$ was applied. Whereas, in Neem (Azadirachta indica) the highest fresh shoot weight (42.75 g) was recorded in Neem under drought. The highest fresh shoot weight due to flooding in Sufeda might be attributed towards high water requirements of sufeda (Eucalyptus camaldulensis).

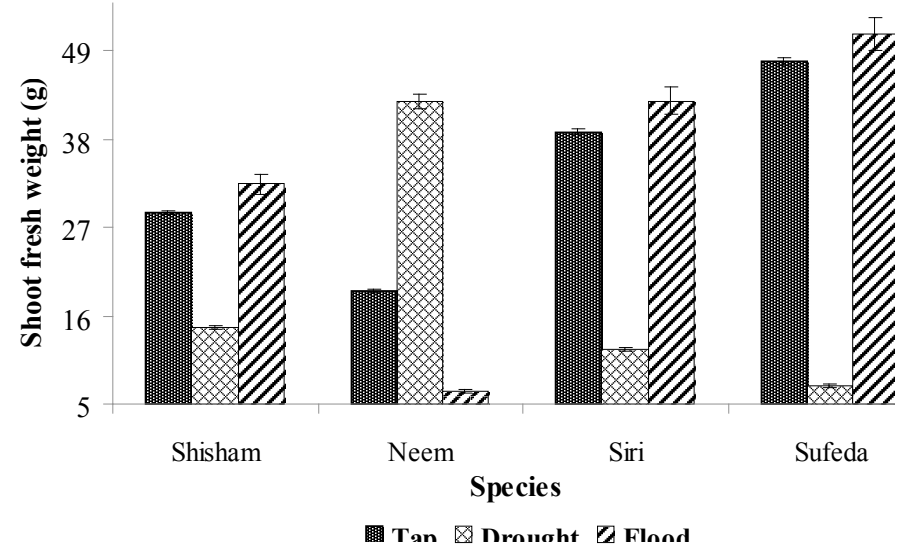

Figure 10: Fresh shoot weight.

Previous findings of Stape et al. (2010) also highlighted $30 \%$ increase the growth parameters of sufeda (Eucalyptus camaldulensis). Different investigations (Campion et al., 2006; Stape et al., 2008) revealed strong positive correlation between water supply and vigorous growth of sufeda (Eucalyptus camaldulensis) especially obvious increase in stem growth up to about 15-35\%. Almeida et al. (2004) also emphasized more on water availability to eucalyptus for best growth. However dissimilar finding were observed in case of Neem (Azadirachta indica) which showed best performance under drought conditions. However, our results are in line with the results of Hunter et al. (2002).

Stape et al. (2010) reported an enhancement of about $30 \%$ in the sufeda (Eucalyptus camaldulensis) growth due to optimum supply of water. Previous findings (Campion et al., 2006) also depicted highly positive correlation between optimum water use and best growth of sufeda (Eucalyptus camaldulensis) with an enormous boost up in eucalyptus growth (15-35\%). Almeida et al. (2004) also focused seriously on optimum water availability to eucalyptus for best growth. However, different results were found in case of Neem (Azadirachta indica) showing best performance under water stress conditions. Nonetheless, our results are parallel to the results of Hunter et al. (2002).

Cui et al. (2009) reported an increase in plant height of jujube tree due to heavy irrigation (i.e flooding). 
This increase in plant height might be attributed towards optimum supply of water which is essential for the growth and development of plants. In the same way water scarcity (i.e drought) exerted stress on the growth of sufeda because of alteration in distribution ratio of the product of photosynthesis among the plant canopy and root. Li et al. (1989) also observed inhibition in plant height of jujube plant due to water deficit (drought) they reported that this inhibition in plant height was due to detrimental effect of drought on vegetative growth of plants. Han et al. (2005) noted similar reduction in vegetative growth of Pear-jujube tree due to drought because of slow growth of plant under water deficit.

Contrary to our results Omar and Kursar (1999) reported $10-30 \%$ reduction in photosynthesis and chlorophyll contents due to flooding. They also highlighted significant drop in root shoot ratio due to flooding. However, Iniesta et al. (2009) reported strong reduction in vegetative growth which was associated with chlorophyll deficiency due to reduced irrigation. However they reported more chlorophyll content in full irrigation because of turgidity of plants due to plenty of available water. Numerous authors (Fernández et al., 1991; Dichio et al., 2002) reported enhanced water use efficiency of Sufeda (Eucalyptus camelduluences) and shesham (Dalbargia sisso) under drought stress environment.

Kang et al. (2007) noted reduced photosynthetic activity with concomitant drop in chlorophyill contents of Pear-jujuba tree under drought environment.

Our results are parallel to the finding of Girona et al. (2003) they reported rapid growth and high root dry weight of pear-jujube tree under flood irrigation because of strong positive correlation between water availability and root growth and development.

Kang et al. (2000) highlighted similar enhancement in dry shoot weight of maize which was cultivated under regulated system of irrigation. Our results are in line with their results as they reported that regulated irrigation showed obvious growth of plant which in turn resulted more dry shoot weight of Sufeda (Eucalyptus camelduluences).

Different studies Greven et al. (2009) showed increased number of branches in olive trees under high irrigation (flooding). Hence, our results are at par with their findings. Sufeda (Eucalyptus camaldulensis) also showed more branches under tap water irrigation. But the Neem (Azadirachta indica) (Neem) performed best under drought conditions indicating highest number of branches. This is because of the fact that Neem (Azadirachta indica) is drought tolerant plant and can show better growth under water stress environment.

Alarcon et al. (2003) also reported likewise findings when apricot was grown under flooding condition because apricot also needs more water for its growth. The highest fresh shoot weight of neem (Azadirachta indica) under drought condition might be due to low water requirements of this plant as it is drought tolerant. Different studies (Abrisqueta et al., 2008; Domingues et al., 2006; Zhang and Fu, 2005) reported parallel results indicating less negative impacts of water stress on fruit trees during earlier stages. $\mathrm{Xu}$ and Chang (2003) reported same results highlighting that water deficit exert very less negative effect during early growth stages in fruit trees.

\section{Author's Contribution}

Muhammad Imran Mahmood collected and analysed the data, wrote the manuscript and did overall management of the article. Muhammad Zubair conceive the idea, provided technical input at every step and supervised the trails.

\section{References}

Abrisqueta, J.M., Mounzer, O., Alvarez, S., Conejero, W., Garcı'a-Orellana, Y., Tapia, L.M., Vera, J., Abrisqueta, I. and Ruiz-Sa'nchez, M.C. 2008. Root dynamics of peach trees submitted to partial rootzone drying and continuous deficit irrigation. Agric. Water Manag. 89: 959-967.

Alarcon, J.J., Domingo, R., Green, S.R., Nicolas, E. and Torrecillas, A. 2003. Estimation of hydraulic conductance within field-grown apricot using sap flow measurements. Plant Soil 251:125-135.

Almeida, A.C., Landsberg, J.J. and Sands, P.J. 2004. Parameterisation of 3-PG model for fast-growing Eucalyptus grandis plantations. Forest Ecol. Manage. 193:179-195. https://doi. org/10.1016/j.foreco.2004.01.029

Alam, S.M., Shaikh, A.H., and Khan, M.A. 2006. 
Depleting forest growth in Pakistan (In press)

Anonymous. 2011. Combating rural poverty and hunger through agroforestry in Bolivia, www. oxfam.org/grow.

Azam, K., Yussof, R.B.M. and Marwat, A.K. 2012. The role of coping capacities in disaster perspective: a case of Pakistan flash floods, 2010. OIDA Int. J. Sustain. Develop. 4 : 109-126.

Cullen, L., Alger, K. and Rambaldi, D.M. 2005. Land reform and biodiversity conservation in Brazil in the 1990s: Conflict and the articulation of mutual interests. Conserv. Biol. 19 : 747755.

Cui, N., Du, T., Kang, S., Li, F., Zhang, J., Wang, M. and Li, Z. 2009. Regulated deficit irrigation improved fruit quality and water use efficiency of pear-jujube trees. Agric. Water Manag. 95: 489-497.

Campion, J., Nkosana, M. and Scholes, M. 2006. Biomass and $\mathrm{N}$ and $\mathrm{P}$ pools in above-and below-ground components of an irrigated and fertilised Eucalyptus grandis stand in South Africa. Aust. For. 69: 48-57. https://doi.org/10. 1080/00049158.2006.10674987

Dale, V.H., Joyce, L.A., McNulty, S., Neilson, R.P., Ayres, M.P., Flannigan, M.D., Hanson, P.J., Irland, L.C., Lugo, A.E. and Peterson, C.J. 2001. Climate change and forest disturbances: climate change can affect forests by altering the frequency, intensity, duration, and timing of fire, drought, introduced species, insect and pathogen outbreaks, hurricanes, windstorms, ice storms, or landslides. BioScience 51:723-734. https://doi. org/10.1641/0006-3568(2001)051[0723:CCAFD]2.0.CO;2

Dichio, B., Romano, M., Nuzzo, V. and Xiloyannis, C. 2002. Soil water availability and relationship between canopy and roots in young olive trees (cv Coratina). Acta Horti. 586: 255-258.

Dilley, M. 2005. "Natural disaster hotspots: a global risk analysis,"World Bank Publications.

Domingues, R., Pérez-Pastor, A. and Ruiz-Sánchez, M.C. 2006. Physiological responses of aprico plants grafted on two different rootstocks to flooding conditions. J. Plant Physiol. 159: 725732.

Douglas, I. 2009. Climate change, flooding and food security in south Asia. Food Sec. 1: 127136.

El-Lakany, H. 2004. Improvement of rural livelihoods: The role of Agroforestry. First World
Agroforest. Cong. 27: 1-4.

EM-DAT. 2010. List of top ten natural disasters in Pakistan. http://www.emdat.be. Excel sheet, (accessed 6 Nov 2010).

Food and Agriculture Organization. 2010. The area of forest under sustainable management. Ananalysis of reports to the Global forest Resources Assessment. Assessment working Paper. Rome, Italy. 119-148. available at www.fao.org/ docrep/013/i1757e/i1757e.

Fernández, J.E., Moreno, F., Cabrera, F., Arrue, J.L. and Martin-Aranda, J. 1991. Drip irrigation, soil characteristics and the root distribution and root activity of olive trees. Plant Soil. 133: 239-251.

Girona, J., Mata, M., Goldhammer, D.A., Johnson, R.S. and DeJong, T.M. 2003. Patterns of soil and tree water status and leaf functioning during regulated deficit irrigation scheduling in peach. J. Am. Soc. Hortic. Sci. 118: 580-586.

Greven, A., Pfaffelhuber P. and Winter, A. 2009. Convergence in distribution of random metric measure spaces $(\Lambda$-coalescent measure trees). Prob. Theor. Fields 145:285-322.

Han, M., Wu, J. and Wang, F. 2005. Redundancy theory and its application in agroecosystem management. Chin. J. Appl. Ecol. 16: 375-378.

Herrera, A. Tezara, W. Marin, O. and Rengifo, E. 2008. Stomatal and non-stomatal limitations of photosynthesis in trees of a tropical seasonally flooded forest. Physiol. Plant. 134: 8-41.

Hirabayashi, Y., Mahendran, R., Koirala, S., Konoshima, L., Yamazaki, D., Watanabe, S., Kim, H. and Kanae, S. 2013. Global flood risk under climate change. Nat. Clim. Change 3: 816-821.

Hunter, I. 2001. Above ground biomass and nutrient uptake of three tree species (Eucalyptuscamaldulensis, Eucalyptus grandis and Dalbergia sissoo) as affected by irrigation and fertiliser, at 3 years of age, in southern India. For. Ecol. Manage. 144: 189-200. https://doi.org/10.1016/ S0378-1127(00)00373-X

Iniesta, F., Testi, L., Orgaz, F. and Villalobos, F.J. 2009. The effects of regulated and continuous deficit irrigation on the water use, growth and yield of olive trees. Eur. J. Agron. 25: 258-265.

Iqbal, M. 1991. Non-timber forest products: their income-generation potential for rural women in North West Frontier Province (Pakistan), 1991; International Labour Organization and Gov- 
ernment of NWFP. Peshawar.

Kang, S., Shi, W. and Zhang, J. 2000. An improved water use efficiency for maize grown under regulated deficit irrigation. Field Crop Res. 67: 207-214.

Kang, S., Du, T., Sun, J. and Ding, R. 2007. Theory and technology of improving irrigation water use efficiency based on crop growing water demand information. J. Hydraulic Eng. 38: 661667.

Kazi, A. 2014. A review of the assessment and mitigation of floods in Sindh, Pakistan. Nat. Hazar. 70: 839-864.

Li, S., Huguet, J.G., Schoch, P.G. and Orlando, P. 1989. Response of peach tree growth and cropping to soil water deficit at various phenological stages of fruit development. Hortic. Sci. 64: 541-552.

Niinemets, U., Hallik, L. and Wright, I.J. 2009. Are species shade and drought tolerance reflected in leaf-level structural and functional differentiation in Northern Hemisphere temperate woody flora? New Phytologist. 184: 257-274.

NDMA, 2010a. National Disaster Management Authority (NDMA) Pakistan Floods institution report. $\mathrm{Pk} /$ images/stories/floods/institution_report/March/27-03-3011 http://www. Pakistanfloods.

NDMA, 2010b. National Disaster Management Authority (NDMA) Pakistan Floods institution report. Available at: http://www.Pakistanfloods.Pk/images/stories/floods/institution_report/March/27-03-3011

MCA (Ministry of Civil Affairs). 2012. China civil affairs' statistical yearbook 2012. Beijing: China Statistics Press (in Chinese).

Omer, M., and Kursar, T.A. 1999. Responses of tropical understory plants to a severe drought: Tolerance and avoidance of water stress. Biotropica. 31:570-8.

Rafiq, L. and Blaschke, T. 2012. Disaster risk and vulnerability in Pakistan at a district level. Geo. Nat. Hazar. Risk. 3: 324-341.Spittlehouse, D.L. and Stewart, R.B. 2004. Adaptation to climate change in forest Management. J. Ecosyst. Manage. 4.

Restrepo, C.L.R., Walker, A.B., Shiels, R.B., Claes- sens, F., Simey, L.P.G., Negi, P.L., Poveda, G., Ramos-Scharron, C., Richter, M., Velazquez, E. 2009. Landsliding and its Multiscale influence on mountains capes. Biosci. 59:685-698. https://doi.org/10.1525/bio.2009.59.8.10

Stape, J.L., Binkley, D., Ryan, M.G., Fonseca, S., Loos, R.A., Takahashi, E.N., Silva, C.R., Silva, S.R., Hakamada, R.E. and Ferreira, J.M.D.A. 2010. The Brazil Eucalyptus Potential Productivity Project: Influence of water, nutrients and stand uniformity on wood production. For. Ecol. Manage. 259:1684-1694. https://doi. org $/ 10.1016 /$ j.foreco.2010.01.012

Sidle, R.C. 2010. Hydrogeomorphic processes: the role of bioclimatic factors, land use, and scale. Geog. Compass. 1-18.

Stape, J.L., Binkley, D., Ryan, M.G., Fonseca, S., Loos, R.A., Takahashi, E.N., Silva, C.R., Silva, S.R., Hakamada, R.E. and Ferreira, J.M.D.A. 2010. The Brazil eucalyptus potential productivity project: Influence of water, nutrients and stand uniformity on wood Production. For. Ecol. Manage. 259: 1684-1694. https://doi. $\mathrm{org} / 10.1016 / \mathrm{j}$.foreco.2010.01.012

Tamale, E., Jones, N. and Riddihough, I.P. 1995. Participatory forestry in tropical and subtropical countries. World Bank for. Series. 299.

UNISDR. 2001. Terminology on disaster risk reduction. United Nations (2009), Geneva.

UNDESA. 2012. The millennium development goal report 2012. New York: United Nations Department of Economic and social affairs.

$\mathrm{Xu}, \mathrm{S}$. and Cheng, X. 2003. Effect of regulated deficit irrigation on yield and quality of Xiangli Pear. Xinjiang Agric. Sci. 40: 6-9.

Wheaton, E.E. Changing fire risk in a changing climate: a literature review and assessment, Saskatchewan Research Council.

Zhang, C. and Fu, Z. 2005. Impact of water stress on the root and shoot growth of litchi seedlings. J. Fruit Sci. 22: 339-342.

Zomer, R.J., Trabucco, A., Coe, R. and Place, F. 2009 Trees on farm: Analysis of globle extent and geographical patterns of agroforestry, World Agroforestry Centre (ICRAF) Working Paper No. 89. Nairobi, Kenya. 